\title{
Protective Effect of Nanjunda Extract and/or Silymarin Against Thioacetamide-induced Hepatic Fibrosis in Rats
}

\author{
B.E. Bayoumy ${ }^{1}$, Akaber T. Keshta ${ }^{* 2}$, Fatma El-Tomy ${ }^{3}$. \\ 1 Professor of organic chemistry, Chemistry department, Faculty of Science, Zagazig University, Egypt. \\ 2 Lecture of biochemistry, Chemistry department, Faculty of Science, Zagazig University, Egypt. \\ 3Biochemistry Division, Chemistry department, Faculty of Science, Zagazig University, Egypt.
}

\begin{tabular}{l}
\hline A R T I C L E I N F O \\
\hline Article history: \\
Received \\
Accepted $X$ \\
Available online \\
Keywords: \\
Nanjunda (Balanites aegyptiaca), \\
oxidative stress, hepato-protective.
\end{tabular}

\section{Introduction}

Liver fibrosis remains one of the serious health problems. Liver fibrosis is part of the structural and functional alterations in most chronic liver diseases ${ }^{(1)}$. During the development of liver fibrosis, activated hepatic stellate cells (HSCs) are able to synthesize and deposit excessive extracellular matrix components into the liver parenchyma ${ }^{(2)}$. Advanced liver fibrosis leads eventually to cirrhosis and liver failure, for which no effective medical treatments are available.

\begin{abstract}
A B S T R A C T
Ackground: Liver fibrosis is a hallmark histologic event of chronic

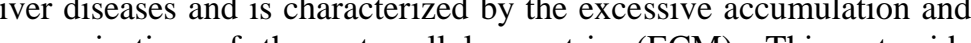
reorganization of the extracellular matrix (ECM). Thioacetamide (TAA) exerts hepatotoxic effects induced liver fibrosis. Herbal plants play a role in the management of various liver disorders most of which speed up the natural healing processes of the liver. One such plant is Nanjunda (Balanites aegyptiaca). Aim: The main purpose of the present study is to evaluate the hepato-protective and antioxidant effects of Nanjunda (Balanites aegyptiaca) extract on liver fibrosis induced by TAA in rats. Materials \& Methods: Swiss male adult albino rats were divided into 5 groups: Group 1, kept as control group; groups 2-5 were injected intraperitoneally (i.p.) with TAA (200 $\mathrm{mg} / \mathrm{Kg}$ ) twice weekly for 8 weeks to induce hepatic fibrosis. Groups 3-5 were administered daily doses of Balanites aegyptiaca extract $(100 \mathrm{mg} / \mathrm{kg})$, Silymarin $(100 \mathrm{mg} / \mathrm{kg})$ and combined treatments, respectively. Results: Our results indicated that TAA caused significant alterations in biochemical and histological manner of liver [increase in serum levels of aminotransferases, metalloproteinase, and galctin-3, elevation in oxidative stress (increase malondialdehyde (MDA), nitric oxide (NO), and decrease antioxidants enzyme activities)].While, administration of Balanites aegyptiaca extract and/or Silymarin attenuated TAA-induced hepatic fibrosis, improved liver enzymes and reduced the oxidative stress. Balanites aegyptiaca extract exhibited a significant effect showing increasing levels of superoxide dismutase (SOD), catalase (CAT), by reducing MDA and NO levels. Conclusion: In conclusion, the combined effect of Nanjunda (Balanites aegyptiaca) extract with Silymarin had powerful hepato-protective and antioxidant effects.
\end{abstract}

(C) 2015 Publisher All rights reserved.

Liver injury induced by various hepatotoxins has been recognized as a major toxicological problem for years ${ }^{(3)}$. Thioacetamide (TAA) is a thionosulfur containing compound. It has been used as a fungicide, organic solvent, accelerator in the vulcanization of rubber, and as a stabilizer of motor oil ${ }^{(4)}$. The toxicity of TAA results from its bio-activation by a mixed-function oxidase system ${ }^{(5)}$. Therefore, prevention of liver fibrosis is a critical step for protecting the liver against 
the occurrence of cirrhosis and failure. Although interferon has been widely used to treat chronic viral hepatitis, the effect of the therapy for liver fibrosis has not always been satisfactory. Herbal medicines have been reported to show protective effects from liver fibrosis and injury ${ }^{(6)}$. Balanites aegyptiaca (L.) Del belongs to the family Balanitaceae. It is commonly known as nanjunda. It has been used in a variety of folk medicine in India and Asia. Various parts of the plant are used in Ayurvedic and other folk medicine for the treatment of various ailments such as syphilis, jaundice, liver and spleen problem, epilepsy and yellow fever and the plant also has insecticidal, antihelminthic, antifeedant, molluscicidal and contraceptive activities ${ }^{(7)}$.

The fruit meso carp contains a large variety of chemicals amongst which are the pregnane glycosides, coumarins, flavonoids, 6methyldiosgenin and saponins ${ }^{(8)}$.The saponins are a structurally and biologically diverse class of glycosides of both steroids and triterpenes that are widely distributed in terrestrial plants and in some marine organisms ${ }^{(9)}$. Galectin-3 is a member of a family of proteins comprising soluble $\beta$ galactoside-binding lectin that appears to be a direct mediator of pro-fibrotic pathways and is a potential marker of adverse cardiac remodeling (10)

The present study is to investigate the anti-fibrotic, Hepato-protective and antioxidant effects of ethanolic extract of Balanites on thioacetamide induced liver fibrosis in male rats.

\section{Materials and Methods}

\section{Plant extraction:}

The ethanolic extract of Balanites aegyptiaca was introduced from Prof. Dr. Faten Zahran.

\section{Chemicals}

Thioacetamide was purchased from Sigma-Aldrich Chemical Co., (St Louis, MO, USA), Galectin 3 (Gal-3) and metalloproteinase-8 (MMP-8) a sandwich ELISA Rat Kit method from (BG Medicine, Waltham, MA).

\section{Animals}

Adult male Swiss albino rats weighing (150-200g) were housed in experimental animal house of the Faculty of Science, Zagazig University. The animals were maintained in controlled environment of temperature, humidity, light, and fed on a commercial standard diet and tap water ad libitum.

\section{Experimental design}

Swiss male adult albino rats were divided into 5 groups: Group 1: Rats received normal saline was served as a normal control; Group 2: fibrotic group: Rats were injected intraperitoneally (i.p.) with TAA $(200 \mathrm{mg} / \mathrm{Kg}){ }^{(11)}$ twice weekly for 8 consecutive weeks. Groups 3 "Balanites treated group": rats were injected intraperitoneally (i.p.) with TAA $(200 \mathrm{mg} / \mathrm{Kg})$ twice weekly for 8 weeks, then administered daily doses of Balanites aegyptiaca extract $(100 \mathrm{mg} / \mathrm{kg}){ }^{(12)}$; Group 4 "Silymarin treated group": rats were injected intraperitoneally (i.p.) with TAA (200 mg/Kg) twice weekly for 8 weeks, then administered Silymarin daily doses of $(100 \mathrm{mg} / \mathrm{kg})$ orally; and Group 5 "combined treatments": rats were injected intraperitoneally (i.p.) with TAA $(200 \mathrm{mg} / \mathrm{Kg})$ twice weekly for 8 weeks, then administered daily doses of Balanites aegyptiaca extract $(100 \mathrm{mg} / \mathrm{kg})$ and Silymarin daily $(100 \mathrm{mg} / \mathrm{kg})$ doses for 28 days. At the end of the experiment animals, animals were weighed then anaesthetized under light diethyl-ether and dissected. Blood samples and liver tissues were collected for biochemical and histopathological analysis.

\section{(A) Biochemical analysis}

Anti-oxidant assays: The plasma was prepared for different antioxidant assays. Malondialdhyde (MDA), nitric oxide (NO) levels, Superoxide dismutase (SOD), and Catalase (CAT) activities, were determined by using Bio-diagnostic kit method according to Satoh ${ }^{(13)}$, Montgomery and Dymock ${ }^{(14)}$, Nishikimi et al., ${ }^{(15)}$, and Aebi ${ }^{(16)}$, methods; respectively.

\section{Liver Biomarkers measurements:}

Galectin-3 (GAL-3) and metalooproteinase-8 (MMP-8) levels were determined by using a sandwich ELISA Rat Kit method in serum according to the method of Christenson et al., ${ }^{(17)}$, and Zhang et al., ${ }^{(18)}$; respectively. Alanine transamines (ALT), asparatate transamines (AST), total protein and albumin were determined by using Bio-diagnostic kit method according to Schumann and Klauke, ${ }^{(19)}$, Karmenet al., ${ }^{(20)}$, Doumas, ${ }^{(21)}$ and Doumaset al., ${ }^{(22)}$ methods; respectively.

\section{(B) Histopathological studies}


Histological evaluation was performed on other portion of the liver tissues. Specimen were fixed in $10 \%$ formalin and embedded in paraffin wax. Liver sections were cut at $5 \mu \mathrm{m}$ in thickness, stained with hematoxylin and eosin (H\&E) and viewed under light microscopy and examined the histological changes according to Lillie, ${ }^{(23)}$

\section{Statistical analysis}

Data were evaluated by one-way analysis of variance (ANOVA)by "SPSS" 14.0 for Microsoft Windows, SPSS Inc. Chicago USA ${ }^{(24)}$ and considered statistically significant at a two-sided $\mathrm{P}<0.05$. Numerical data were expressed as mean \pm $\mathrm{SD}$.

\section{Results}

\section{Effect of Balanites aegyptiaca extract on} antioxidants in all studied groups:

Table (1) summarized the mean values of MDA, NO, SOD, and CAT in all groups. On a hand, the mean value of MDA and NO levels were found to be $18.7 \pm 1.3(\mathrm{nmol} / \mathrm{ml})$, and $25.0 \pm 2.1(\mu \mathrm{mol} / 1)$ in negative control group; respectively. Fibrotic group showed a significant increase in both MDA levels to be $67.3 \pm 6.0(\mathrm{nmol} / \mathrm{ml})$ by $259.8 \%$, and NO levels to be $76.0 \pm 9.4(\mu \mathrm{mol} / 1)$ by $204.0 \%$, $(\mathrm{p}<0.001)$ compared to negative control group. While, administration of Banalities extract, Silymarin alone or in combination resulted in a significant decrease in MDA levels to $36.6 \pm 1.0$, $39.9 \pm 4.2$, and $22.4 \pm 0.9(\mathrm{nmol} / \mathrm{ml})$ by $45.6 \%$, $40.7 \%$, and $66.7 \%, \quad(\mathrm{p}<0.001)$ respectively; compared to the fibrotic group. Also, NO levels were decreased significantly in Banalities extract, Silymarin and combination groups to $32.4 \pm 1.8$, $37.9 \pm 1.6$, and $28.4 \pm 0.8(\mu \mathrm{mol} / 1)$ by $57.4 \%, 50.1 \%$, and $62.6 \%$, respectively, $(\mathrm{p}<0.001)$ compared to fibrotic group.

On the other hand; CAT and SOD activities were decreased from 236.1 \pm 10.0 (U/l), $141.8 \pm 9.0(\mathrm{U} / \mathrm{ml})$ in negative control group to $97.8 \pm 4.2,75.1 \pm 5.4$ in fibrotic group by $58.6 \%$, and $47.0 \%$ a; respectively, $(\mathrm{p}<0.001)$. While, their activities were significantly increased to $213.7 \pm 10.9$, and $157.3 \pm 12.1$ in Banalities group, to $199.1 \pm 6.7$ and, $114.5 \pm 9.8$ in Silymarin group, and to $354.1 \pm 30.3$, and $226.6 \pm 20.4$ by $262.1 \%, 201.7 \%$ in combination group; respectively, $(\mathrm{p}<0.001)$ compared to fibrotic group.
Effect of Balanites aegyptiaca extract on liver functions in all studied groups:

Table (2) summarized the effect of extract on liver function tests in sera of studied groups. Measurement of liver enzyme activities demonstrated significant increase in ALT, and AST activities in fibrotic group to $96.8 \pm 4.6$, and $217.6 \pm 3.6$ (U/L) by $185.7 \%, 290.5 \%$, and $109.4 \%$; respectively compared to negative control group, $(\mathrm{p}<0.001)$. These high activities of liver enzymes were significantly reduced to $42.8 \pm 1.4$, and 154.2 \pm 1.1 by $-55.8 \%$, and $29.1 \%$; respectively in Banalities group, to $61.3 \pm 3.3$ and, $148.1 \pm 6.1$ by $36.7 \%$, and $31.9 \%$ in Silymarin group, and to $55.3 \pm 4.0$, and $124.8 \pm 2.8$ by $42.9 \%$, and $42.6 \%$ in combination group; respectively, $\quad(\mathrm{p}<0.001)$ compared to fibrotic group. Also, enzyme ratio decreased in fibrotic group and then this ratio was increased as a result of administration of treatments.

Total proteins and albumin concentrations were significantly decreased in fibrotic group from $9.7 \pm 0.3$ to $7.7 \pm 0.4(\mathrm{~g} / \mathrm{dl})$ by $20.6 \%$, and from $4.1 \pm 4.50 .21$ to $2.7 \pm 0.2 \quad(\mathrm{~g} / \mathrm{dl})$ by $34.1 \%$; respectively, $(\mathrm{p}<0.01)$ compared to negative control group. These concentrations were significantly increased to $9.3 \pm 0.1$, and $4.1 \pm 0.07$ by $20.8 \%$, and $51.9 \%$; respectively in Banalities group, to $8.0 \pm 0.09$ and, $3.6 \pm 0.4$ by $3.8 \%$, and $33.3 \%$ in Silymarin group, and to $9.0 \pm 0.07$, and $4.1 \pm 0.1$ by $16.9 \%$ and $51.8 \%$ in combination group; respectively, $(\mathrm{p}<0.001)$ compared to fibrotic group.

Effect of Balanites aegyptiaca extract on Gal-3 concentrations and MMP-8 activity in all studied groups:

Gal-3 concentrations and MMP-8 activities were demonstrated in table (3) in all studied groups.

Gal-3 and MMP-8 were significantly elevated in the fibrotic group to $20.7 \pm 2.1(\mathrm{ng} / \mathrm{ml}) \& 451.7$ \pm 19.6 ( $\mathrm{pg} / \mathrm{ml})$; respectively compared to negative control group $3.7 \pm 0.08 \& 83.5 \pm 7.6$ by $459.5 \%$ \& 440.9\%; respectively ( $\mathrm{p}<0.001)$.

Meanwhile, Gal-3 and MMP-8 were significantly decreased to $5.6 \pm 0.3$, and $197.1 \pm 6.4$ by $72.9 \%$, and $56.4 \%$; respectively in Banalities group, to 8.3 \pm 0.3 and, $278.4 \pm 22.7$ by $59.9 \%$, and $38.4 \%$ in Silymarin group, and to $4.3 \pm 0.4$, and $116.4 \pm 8.6$ by $79.2 \%$ and $74.2 \%$ in combination group; respectively, $(\mathrm{p}<0.001)$ compared to fibrotic group. 
Histological studies in all studied groups:

The histological examinations of liver tissues with Hematoxylin and Eosin stain in the different studied groups confirm the biochemical study in all different groups, as shown in Fig. (1 A, B, C, D, E).

The histological examination of control rats (Negative control Group) revealed that, the normal histological appearance of liver with clearly outlined figs of hepatocytes along with adjacent sinusoids radiating from the central veins towards periphery of liver lobule. However, Fibrotic Group showed disturbance of the normal architecture of liver tissue. Histological abnormality in the fibrotic model rat was characterized by depositing bundles of collagens in the pericentral and midzonal areas of liver tissues.

Nevertheless, Banalities group showed showing congestion of the hepatoportal blood vessel. Silymarin group showed mild liver affection, as liver showing congested blood vessel. Combination group demonstrated marked regression of the degree of fibrosis with a large amount of alleviation in abnormal area compared with model group and almost similar to normal group.

\section{Discussion}

Liver fibrosis is part of the structural and functional alterations in most chronic liver diseases. It is one of the main prognostic factors as the amount of fibrosis is correlated with the risk of developing cirrhosis and liver-related complications in viral and non-viral chronic liver diseases ${ }^{(1)}$. Establishing an easy and reproducible model for hepatic fibrosis is absolutely necessary for research on liver reperfusion injury. The animal model of hepatic fibrosis is important for experimental research to apply to clinical uses for reperfusion injury or anti-fibrosis (26). Among various hepatotoxins, TAA is known to be the most potent because of its rapid elimination and cumulative injury. In the present study, TAA induced elevation of MDA and NO levels, reductions of endogenous antioxidant enzymes (SOD and CAT). It was suggested that TAA induced liver fibrosis by forming free radicals, which then react with cellular lipids to promote lipid peroxidation ${ }^{(27)}$. The higher MDA level in TAA control rats observed in the present study also supports this suggestion. The hepatotoxicity of TAA results from its metabolic conversion to free radical products: thioacetamide sulfoxide and thioacetamide-S, S-dioxide which attacks microsomal lipids leading to their peroxidation and production of reactive oxygen species (ROS), such as the $\mathrm{H}_{2} \mathrm{O}_{2}$, super oxide anion $\mathrm{O}_{2}-$, and the hydroxyl radical. ROS affects the antioxidant defense mechanisms, decreases the activity of SOD that causes liver injury, cirrhosis development, and hepatocarcinoma ${ }^{(28)}$. While the treatments with ethanol extract of Balanites aegyptiaca or/and Silymarin significantly reversed these changes and showing a significant improvement of the oxidative stress in these animals. It may be possible that the mechanism of hepato-protection by ethanol extraction of Balanites aegyptiaca is due to its antioxidant effect ${ }^{(12)}$. Mohan et al., ${ }^{(28)}$ stated that the saponins of ethanol extract of Balanites aegyptiaca was able to stabilize reactive oxygen species by reacting with them and oxidizes subsequently to more stable and less reactive radicals ${ }^{(12)}$. Also, balanitoside has significant inhibition on NO formation that might be due to its antiinflammatory effect. Lawrence et al., ${ }^{(30)}$ reported that flavonoids of Silybum marianum (Silymarin) had potent antioxidant effect, indicated by significant increase of superoxide anions, and lipid oxygen radicals due to lipid peroxidation as proven in this study. Several investigators previously reported the potent in vivo antioxidant activity of Silybium marianum, they referred it's in vivo antioxidant activity via increasing the levels of glutathione, which is an important antioxidant that detoxifies an array of hormones, drugs and chemicals ${ }^{(31)}$. These findings are consistent with previous investigations which indicated that TAA caused a significant decrease in the levels of liver SOD and CAT ${ }^{(32)}$. Our results are in agreement with Mayba et al., (12) who reported that the increase in malondialdehyde (MDA) levels in liver suggests enhanced lipid peroxidation leading to tissue damage and failure of antioxidant defense mechanisms to prevent formation of excessive free radicals. Treatment with ethanol extract of Balanites aegyptiaca significantly reversed these changes, and it may be possible that the mechanism of hepato-protection by ethanol extraction of Balanites aegyptiaca is due to its antioxidant effect. 
Serum liver biomarkers (ALT, AST) are important criteria for the evaluation of liver toxicity. The amounts of enzymes that leak into the blood stream indicate the severity of hepatic damage ${ }^{(33)}$. In the present study, the rats intoxicated with TAA experienced hepatic injury evidenced by significant increase in serum liver biomarkers (AST and ALT) when compared to normal control rats. However, ethanol extract of Balanites aegyptiaca or/and Silymarin significantly exhibited hepato-protective effects to attenuate the elevated serum liver parameters, but the effectiveness of ethanol extract of Balanites aegyptiaca in the attenuation of the elevated liver enzymes was observed more in combined treated group than single treated one. The increased serum levels of AST and ALT are due to the damage to the structural integrity of the liver, since these enzymes are normally located in the cytoplasm and released into the circulation after cellular injury ${ }^{(34)}$. Also Hajovsky et al., ${ }^{(35)}$ reported that thioacetamide produces free radicals, which affect the cellular permeability of hepatocytes leading to elevated levels of serum biochemical parameters like ALT, and AST. Administration of TAA for a period of 10 weeks increased the levels of serum ALT, AST, while the levels of total protein, and albumin were statistically decreased in experimental male rats ${ }^{(36)}$. As Balanties and Silymarin have both hepato-protective and regenerative actions. Our results are in agreement with Abdel-Salam et al., ${ }^{(37)}$ reported that the Silymarin decreased leakage of hepatocellular enzymes ALT and AST into the plasma, and lessened the development of liver necrosis and fibrosis caused by carbon tetrachloride $\left(\mathrm{CCl}_{4}\right)$. Our results revealed that, galctin-3 and MMP-8 were increased in induced hepatic fibrosis as a result of activation of hepatic stellate cells (HSCs), while Balanites and/or Silymarin reduce these alterations. Central to fibrogenesis and the scarring of organs is the activation of fibroblasts into matrix-secreting myofibroblasts. Galectin-3 expression is up-regulated in established human fibrotic liver disease and is temporally and spatially related to the induction and resolution of experimental hepatic fibrosis. Disruption of the Galectin-3 gene blocks myofibroblast activation and procollagen (I) expression in vitro and in vivo, markedly attenuating liver fibrosis. These data suggest that Galectin-3 is required for TGF- $\beta$ mediated myofibroblast activation and matrix production ${ }^{(38)}$. It has been suggested recently that the therapeutic strategy for protecting against oxidative stress will be to target simultaneously the free radicals in both the lipid and the aqueous phases, in extracellular and intracellular spaces ${ }^{(39)}$. To confirm our biochemical data, Histopathological study was done. Histologically, in our study, TAA administration produced depositing bundles of collagens in the pericentral and mid-zonal areas of liver tissues. The posttreatment of animals with Balanites aegyptiaca or/and Silymarin, reversed significantly TAAintoxicated pathogenic changes in liver. These findings were line with Saad et al., ${ }^{(40)}$, acute TAA toxicity leads to the prominent changes in the liver tissue architecture including the appearance of necrotic cells and inflammatory cells, mostly macrophages around the central vein. TAA produces centrilobular necrosis.

\section{Conclusion:}

In conclusion Balanites aegyptiaca extract may be has a significant anti-fibrotic and antioxidant effect on the liver fibrosis induced by thioacetamide. As Balanites aegyptiaca extract and Silymarin reverse the hepatic biochemical and histological alterations induced by thioacetamide.

\section{References}

1. European Association For the Study of the Liver (EASL), and Association Latinomericana Para el Estudio del Higado (ALEH) (2015): EASL-ALEH Clinical Practice Guidelines: Noninvasive tests foe evaluation of liver disease severity and prognosis. Journal of Hepatology, 63, 237-264.

2. Friedman S.L., (2003): Liver fibrosis-from bench to bedside. J. Hepatol. 38 (Suppl 1), S38S53.

3. Sakthidevi G., and Mohan V.R., (2013): Hepato-protective and antioxidant effect of Polygala chinensis $L$. whole plant against $\mathrm{CCl}_{4}$ induced hepatotoxicity in rats. International Journal of Biomedical and Advance Research, 4 (11): 806-812.

4. Chilakapati J., Shankar K., Korrapati M.C., Hill R.A., and Mehendale H.M., (2005): Saturation toxicokinetics of thioacetamide: role in initiation of liver injury. Drug Metab Dispos, 33: $1877-1885$ 
5. Hsieh, C.C., Fang, H.L., Lina, W.C., (2008): Inhibitory effect of Solanum nigrum on thioacetamide-induced liver fibrosis in mice. $J$. Ethnopharmacol. 119, 117-121.

6. Yadhav J.P., and Panghal M., (2010): Balanites aegyptisaca (L.) Del. (Hingot): A review of its traditional uses, phytochemistry and pharmacological properties. International Journal of Green Pharmacy; 4: 140-146.

7. Koko W.S., Galal M., and Khalid H.S., (2005): Fasciolicidal efficacy of Albizia anthelmintica and Balanites aegyptiaca compared with albendazole. J Ethnopharmacol.; 71: 247-252. 8. Deng S., Yu B., Hui Y., Yu H., and Han X., (1999): Synthesis of three diosgenyl saponins: dioscin, polyphyllin D and balanitin-7. Carbohydrate Res., 317: 53-62.

9. Marnewick J.L., van der Westhuizen F.H., Joubert E., Swanevelder S., Swart P., and Gelderblom W.C.A., (2009): Chemoprotective properties of rooibos (Aspalathus linearis), honeybush (Cyclopia intermedia) herbal and green and black (Camellia sinensis) teas against cancer promotion induced by fumonisin B1 in rat liver. Food and Chemical Toxicology, 47, 220- 229.

10. Joubert E., Winterton P., Britz T.J. and Ferreira D., (2004): Superoxide anion radical and $\alpha, \alpha$-diphenyl-B-picrylhydrazyl radical scavenging capacity of rooibos (Aspalathus linearis) aqueous extracts, crude phenolic fractions, tannin and flavonoids. Food Res. Int., 37 pp. 133-138.

11. Barash H., Gross E., Edrei Y., Pappo O., Spira G., Vlodavsky I., Galun E., Matot I. and Abramovitch R., (2008): Functional magnetic resonance imaging monitoring of pathological changes in rodent livers during hyperoxia and hypercapnia. Hepatology; 48:1232-1241.

12. Mayba T.G.S., Parthipan B., Kingston C., Mohan V.R., and Tresina P.s., (2011): Hepatoprotective and antioxidant effect of Balanites aegyptisaca (L.) Del. against CCL4 induced hepatotoxicity. IJPSR, 2(3): 887-892.

13. Satoh K., (1978): Serum Lipid Peroxide in cerebrovascular disorders determined by a new colorimetric method. Clinica Chimica Acta 90:3743.

14. Montgomery H.C., and Dymock J.F., (1961): The determination of nitrite in water. Analyst 86: 414- 416.
15. Nishikimi M., Appaji N., and Yogi K., (1972): The occurrence of superoxide anion in the reaction of reduced phenazinemethosulfate and molecular oxygen. Biochem. Bioph. Res. Commun46: 849 - 854 .

16. Aebi H., (1984): Catalase in vitro, Methods Enzymol 6:105:121.

17. Christenson R.H., Duh S.H., Wu A.H., Smith A., Abel G., deFilippi C.R., Wang S., Adourian A., Adiletto C., and Gardiner P., ( 2010): Multi-center determination of galectin-3 assay performance characteristics anatomy of a novel assay for use in heart failure. ClinBiochem; 43:683-90.

18. Zhang S., Tang X., Tian J., Li C., Zhang G., Jiang W., and Zhang Z., (2011): Cardioprotective Effect of Sulphonated Formononetin on Acute Myocardial Infarction in Rats. Basic \& Clinical Pharmacology \&Toxicology, 108(6):390-5.

19. Schumann G. and Klauke R., (2003): New IFCC reference procedures for the determination of catalytic activity concentrations of five enzymes in serum: preliminary upper reference limits obtained in hospitalized subjects. J. Clin. Chim. Acta., 327: 69-79.

20. Karmen A., Wroblewski F. and LaDue I.S.,(1955): Transaminase activity in human blood. J.Clin Invest.,34:126.

21. Doumas B.T., (1975): Standard methods of protein determination. J. Clin. Chem., 7: 175-188. 22. Doumas B.T., Watson W.A., and Biggs H.G., (1971): Albumin standards and the measurement of serum albumin with bromocresol green. J. Clin. Chem., 31: 87-96.

23. Lillie R.D., (1976): Histopathologic technique. Practical histochemistry. 95: 851-859.

24. Levesque R., (2007): Programming and Data Management: A Guide for SPSS and SAS Users, Fourth Edition, SPSS Inc., Chicago Ill.

25. Alboraie M., (2015): Assessment of Hepatic Fibrosis in 2015, what should the Clinicians know?. J Liver Res Disord Ther 1(1): 00002.

26. Jang J.H., Kang K.J., Kim Y.H., Kang Y.N., and Lee I.S., (2008): Reevaluation of Experimental Model of Hepatic Fibrosis Induced by Hepatotoxic Drugs: An Easy, Applicable, and Reproducible Model. Transplantation Proceedings, 40, 2700-2703.

27. Fadhel Z.A., and Amran S., (2002): Effects of black tea extract on carbon tetrachloride-induced 
lipid peroxidation in liver, kidneys, and testes of rats, Phytotherapy Research 16 (10): S28-S32.

28. Poli G.; (2000): "Pathogenesis of liver fibrosis: role of oxidative stress," Molecular Aspects of Medicine, 21 (3): 49-98.

29. Mohan V R , Mayba G S T, Parthipan B, Kingston C, and Tresina S P., (2011): Hepatoprotective And Antioxidant Effect Of Balanites aegyptiaca (L.) Del against $\mathrm{Ccl} 4$ Induced Hepatotoxicity in Rats. Int. J.Pharm.; 2(3): 887892.

30. Lawrence, V., Jacobs, B., Dennehy, and C., (2000): Milk Thistle: Effects on liver disease and cirrhosis and clinical adverse effects. Rockville (MD) Agency for Healthcare Research and Quality, City, USA.

31. Shaker E., Mahmoud H., and Mnaa S., (2010): Silymarin, the antioxidant component and Silybum marianum extracts prevent liver damage. Food Chem. Toxicol. 48 (3), 803-806.

32. Kantah M.K., Kobayashi R., Sollano J. et al., (2011): "Hepatoprotective activity of a phytotherapeutic formula on thioacetamideinduced liver fibrosis model," Acta Bio Medica, vol. 82, no. 1,pp. 82-89.

33. Abul Najmi K., Pillai K.K., Pal S.N., Akhtar M., Aqil M., and Sharma M., (2010): Effect of 1ornithine 1-aspartate against thioacetamideinduced hepatic damage in rats, Indian Journal of Pharmacology, 42 (6): 384-387.

34. Shim J.Y., Kim M.H., Kim H.D., Ahn J.Y., Yun Y.S., Song J.Y. (2010): Protective action of the immunomodulator ginsan against carbon tetrachloride-induced liver injury via control of oxidative stress and the inflammatory response. Toxicology and Applied Pharmacology, 242:318325.
35. Hajovsky H., Hu G., Koen Y. , Sarma D., Cui W., Moore D.S., Staudinger J.L., and Hanzlik R.P., (2012): Metabolism and toxicity of thioacetamide and thioacetamide S-oxide in rat hepatocytes, Chemical Research in Toxicology, 25 (9):1955-1963.

36. Al-Attar A. M., (2011): "Hepato-protective influence of vitamin $\mathrm{C}$ on thioacetamide-induced liver cirrhosis in Wistar male rats," Journal of Pharmacology and Toxicology, 6 (3): 218-233.

37. Abdel-Salam O.M., Sleem A.A., and Morsy F.A., (2007): Effects of biphenyldimethyldicarboxylate administration alone or combined with silymarin in the CCL4 model of liver fibrosis in rats. The Scientific World Journal 7: 1242-1255. 38. Henderson Neil C., Alison C. Mackinnon, Sarah L. Farnworth, Francoise Poirier, Francesco P. Russo, John P. Iredale, Christopher Haslett, Kenneth J. Simpson, and Tariq Sethi (2006): Centre for Inflammation Research, Queens Medical Research Institute, University of Edinburgh, 51 Little France Crescent, EH16 4SA Edinburgh, Scotland,United Kingdom, and Laboratoire de Genetique et Developpement des Mammiferes, Institut Jacques Monod, 2, Place Jussieu, 75251 Paris Cedex 05, France 5060-5065 PNAS vol. 103 no. 13.

39. Vendemiale G., Grattagliano I., and Altomare E., (1999): An update on the role of free radicals and antioxidant defense in human disease, International Journal of Clinical \& Laboratory Research, 29 (2): 49-55.

40. Saad Ramadan A., Mohamed Fath EL-Bab, Abir A. Shalaby, (2013): Attenuation of acute wand chronic liver injury by melatonin in rats. Journal of Taibah University for Science, 7: 88-96 
Table (1): Non-enzymatic and Enzymatic anti-oxidants in all studied groups::

\begin{tabular}{|c|c|c|c|c|c|c|c|c|c|c|}
\hline \multirow[t]{2}{*}{ Variables } & \multicolumn{2}{|c|}{$\begin{array}{l}\text { Negative control } \\
\text { Group (1) }\end{array}$} & \multicolumn{2}{|c|}{$\begin{array}{l}\text { Fibrotic Group" } \\
\text { (2) }\end{array}$} & \multicolumn{2}{|c|}{$\begin{array}{c}\text { Banalities Group } \\
\text { (3) }\end{array}$} & \multicolumn{2}{|c|}{$\begin{array}{c}\text { Silymarin Group } \\
\text { (4) }\end{array}$} & \multicolumn{2}{|c|}{$\begin{array}{c}\text { Combination } \\
\text { Group (Banalities } \\
+ \text { Silymarin) (5) }\end{array}$} \\
\hline & $\begin{array}{l}\text { Mean } \pm \\
\text { SD. }\end{array}$ & $\begin{array}{c}\% \\
\text { Cha } \\
\text { nge }\end{array}$ & $\begin{array}{l}\text { Mean士 } \\
\text { SD. }\end{array}$ & $\begin{array}{c}\% \\
\text { Change }\end{array}$ & $\begin{array}{l}\text { Mean士 } \\
\text { SD. }\end{array}$ & $\begin{array}{l}\% \\
\text { Cha } \\
\text { nge }\end{array}$ & $\begin{array}{l}\text { Mean } \pm \\
\text { SD. }\end{array}$ & $\begin{array}{l}\% \\
\text { Cha } \\
\text { nge }\end{array}$ & $\begin{array}{l}\text { Mean } \pm \\
\text { SD. }\end{array}$ & $\begin{array}{c}\% \\
\text { Chan } \\
\text { ge }\end{array}$ \\
\hline $\begin{array}{c}\text { MDA } \\
(\mathrm{nmol} / \mathrm{ml})\end{array}$ & $18.7 \pm 1.3$ & ---- & $\begin{array}{l}67.3 * * * \\
\pm 6.0\end{array}$ & $259.8 \%$ & $\begin{array}{c}36.6 \\
\pm 1.0 * *\end{array}$ & $\begin{array}{c}- \\
45.6 \\
\%\end{array}$ & $\begin{array}{c}39.9 \pm 4.2 \\
* *\end{array}$ & $\begin{array}{c}- \\
40.7 \\
\%\end{array}$ & $\begin{array}{l}22.4 \pm 0.9 \\
* * *\end{array}$ & $\begin{array}{c}- \\
66.7 \\
\%\end{array}$ \\
\hline $\begin{array}{c}\text { NO } \\
(\mu \mathrm{mol} / \mathrm{l})\end{array}$ & $25.0 \pm 2.1$ & ---- & $\begin{array}{c}76.0 \\
\pm 9.4 * * *\end{array}$ & $204.0 \%$ & $\begin{array}{c}32.4 \\
\pm 1.8 * *\end{array}$ & $\begin{array}{c}- \\
57.4 \\
\%\end{array}$ & $\begin{array}{c}37.9 \pm 1.6 \\
* *\end{array}$ & $\begin{array}{c}- \\
50.1 \\
\%\end{array}$ & $\begin{array}{l}28.4 \pm 0.8 \\
* * *\end{array}$ & $\begin{array}{l}- \\
62.6 \\
\%\end{array}$ \\
\hline $\begin{array}{l}\text { CAT } \\
(\mathbf{U} / \mathbf{L})\end{array}$ & $\begin{array}{c}236.1 \pm 10 \\
.0\end{array}$ & ----- & $\begin{array}{l}97.8 * * * \\
\pm 4.2\end{array}$ & $-58.6 \%$ & $\begin{array}{c}213.7 \pm 10 \\
.9 * * *\end{array}$ & $\begin{array}{l}118 . \\
5 \%\end{array}$ & $\begin{array}{l}199.1 * * * \\
\quad \pm 6.7\end{array}$ & $\begin{array}{c}103.6 \\
\%\end{array}$ & $\begin{array}{c}354.1 \pm 30 \\
.3 * * *\end{array}$ & $\begin{array}{c}262.1 \\
\%\end{array}$ \\
\hline $\begin{array}{c}\text { SOD } \\
(\mathbf{U} / \mathrm{ml})\end{array}$ & $\begin{array}{c}141.8 \pm 9 \\
0\end{array}$ & ----- & $\begin{array}{c}75.1 \pm 5 \\
4 * * *\end{array}$ & $-47.0 \%$ & $\begin{array}{c}157.3 \pm 12 \\
.1 * * *\end{array}$ & $\begin{array}{l}109 . \\
5 \%\end{array}$ & $\begin{array}{c}114.5 \pm 9 . \\
8 * * *\end{array}$ & $\begin{array}{c}52.5 \\
\%\end{array}$ & $\begin{array}{c}226.6 \pm 20 \\
.4 * * *\end{array}$ & $\begin{array}{c}201.7 \\
\%\end{array}$ \\
\hline
\end{tabular}

Significant difference at $(* \mathbf{P}<0.05, * * \mathbf{P}<0.01, * * * \mathbf{P}<0.001)$

Table (2): Liver functions in all studied groups:

\begin{tabular}{|c|c|c|c|c|c|c|c|c|c|c|}
\hline \multirow[t]{2}{*}{ Variables } & \multicolumn{2}{|c|}{$\begin{array}{l}\text { Negative control } \\
\text { Group (1) }\end{array}$} & \multicolumn{2}{|c|}{$\begin{array}{c}\text { Fibrotic } \\
\text { Group (2) }\end{array}$} & \multicolumn{2}{|c|}{$\begin{array}{l}\text { Banalities } \\
\text { Group (3) }\end{array}$} & \multicolumn{2}{|c|}{$\begin{array}{l}\text { Silymarin } \\
\text { Group (4) }\end{array}$} & \multicolumn{2}{|c|}{$\begin{array}{c}\text { Combination } \\
\text { Group (Banalities } \\
\text { +Silymarin) }(5) \\
\end{array}$} \\
\hline & $\begin{array}{c}\text { Mean } \pm \\
\text { SD. }\end{array}$ & $\begin{array}{c}\% \\
\text { Chang } \\
\text { e }\end{array}$ & $\begin{array}{l}\text { Mean } \pm \\
\text { SD. }\end{array}$ & $\begin{array}{c}\% \\
\text { Chan } \\
\text { ge }\end{array}$ & $\begin{array}{l}\text { Mean } \pm \\
\text { SD. }\end{array}$ & $\begin{array}{c}\% \\
\text { Chang } \\
\text { e }\end{array}$ & $\begin{array}{l}\text { Mean } \pm \\
\text { SD. }\end{array}$ & $\begin{array}{c}\% \\
\text { Chan } \\
\text { ge }\end{array}$ & $\begin{array}{l}\text { Mean } \pm \\
\text { SD. }\end{array}$ & $\begin{array}{c}\% \\
\text { Change }\end{array}$ \\
\hline $\begin{array}{l}\text { ALT } \\
(\mathbf{U} / \mathbf{L})\end{array}$ & $63.9 \pm 6.1$ & ------- & $\begin{array}{c}96.8 * * \\
\pm 4.6\end{array}$ & $\begin{array}{c}51.5 \\
\%\end{array}$ & $\begin{array}{c}42.8 \\
\pm 1.4 * *\end{array}$ & $55.8 \%$ & $\begin{array}{c}61.3 \pm 3 \\
.3 * *\end{array}$ & $36.7 \%$ & $\begin{array}{c}55.3 \pm 4 \\
0 * *\end{array}$ & $-42.9 \%$ \\
\hline $\begin{array}{c}\text { AST } \\
(\mathbf{U} / \mathbf{L})\end{array}$ & $97.8 \pm 5.3$ & ------- & $\begin{array}{c}217.6 * * \\
\pm 3.6\end{array}$ & $\begin{array}{c}122.5 \\
\%\end{array}$ & $\begin{array}{c}154.2 * * \\
\pm 1.1\end{array}$ & $29.1 \%$ & $\begin{array}{c}148.1 \pm \\
6.1 * *\end{array}$ & - & $\begin{array}{c}124.8 \pm 2 \\
.8 * *\end{array}$ & $-42.6 \%$ \\
\hline$\underset{(\mathrm{g} / \mathrm{dl})}{\mathbf{T P}}$ & $9.7 \pm 0.3$ & ------- & $\begin{array}{c}7.7 \\
\pm 0.4^{* *}\end{array}$ & $\begin{array}{c}- \\
20.6 \\
\%\end{array}$ & $\begin{array}{c}9.3 \pm 0.1 * \\
*\end{array}$ & $20.8 \%$ & $\begin{array}{c}8.0 \\
\pm 0.09 * \\
*\end{array}$ & $3.8 \%$ & $\begin{array}{c}9.0 \pm 0.0 \\
7 * *\end{array}$ & $16.9 \%$ \\
\hline $\begin{array}{l}\text { Albumin } \\
\text { (g/dl) }\end{array}$ & $\begin{array}{c}4.1 \pm 4.50 \\
.21\end{array}$ & ------- & $\begin{array}{c}2.7 \pm 0.2 * \\
*\end{array}$ & $\begin{array}{c}- \\
34.1 \\
\%\end{array}$ & $\begin{array}{c}4.1 \pm 0.07 \\
* *\end{array}$ & $51.9 \%$ & $\begin{array}{c}3.6 \pm 0 \\
4 * *\end{array}$ & $33.3 \%$ & $\begin{array}{c}4.1 \pm 0.1 \\
* *\end{array}$ & $51.8 \%$ \\
\hline
\end{tabular}


Table (3): Gal-3 concentration and MMP-8 activity in all studied groups:

\begin{tabular}{|c|c|c|c|c|c|c|c|c|c|c|}
\hline \multirow[t]{2}{*}{ Variables } & \multicolumn{2}{|c|}{$\begin{array}{l}\text { Negative control } \\
\text { Group (1) }\end{array}$} & \multicolumn{2}{|c|}{$\begin{array}{l}\text { Fibrotic Group" } \\
\text { (2) }\end{array}$} & \multicolumn{2}{|c|}{$\begin{array}{c}\text { Banalities Group } \\
\text { (3) }\end{array}$} & \multicolumn{2}{|c|}{$\begin{array}{l}\text { Silymarin Group } \\
(4)\end{array}$} & \multicolumn{2}{|c|}{$\begin{array}{c}\text { Combination } \\
\text { Group (Banalities } \\
+ \text { Silymarin) (5) }\end{array}$} \\
\hline & $\begin{array}{l}\text { Mean } \\
\pm \text { SD. }\end{array}$ & $\begin{array}{c}\% \\
\text { Chang } \\
\text { e }\end{array}$ & $\begin{array}{l}\text { Mean } \pm \\
\text { SD. }\end{array}$ & $\begin{array}{c}\% \\
\text { Chang } \\
\text { e }\end{array}$ & $\begin{array}{l}\text { Mean } \pm \\
\text { SD. }\end{array}$ & $\begin{array}{c}\% \\
\text { Chang } \\
\text { e }\end{array}$ & $\begin{array}{l}\text { Mean } \pm \\
\text { SD. }\end{array}$ & $\begin{array}{c}\% \\
\text { Chang } \\
\text { e }\end{array}$ & $\begin{array}{l}\text { Mean } \pm \\
\text { SD. }\end{array}$ & $\begin{array}{c}\% \\
\text { Chang } \\
\text { e }\end{array}$ \\
\hline $\begin{array}{l}\text { Gal-3 } \\
(\mathbf{n g} / \mathbf{m l})\end{array}$ & $\begin{array}{l}3.7 \pm 0 . \\
08\end{array}$ & ------- & $\begin{array}{l}20.7 \\
\pm 2.1 * * *\end{array}$ & $459.5 \%$ & $\begin{array}{c}5.6 \\
\pm 0.3^{* * *}\end{array}$ & $-72.9 \%$ & $\begin{array}{c}8.3 \\
\pm 0.3 * * \\
*\end{array}$ & $59.9 \%$ & $\begin{array}{c}4.3 \pm 0.4 * \\
* *\end{array}$ & $-79.2 \%$ \\
\hline $\begin{array}{c}\text { MMP-8 } \\
(\mathrm{pg} / \mathrm{ml})\end{array}$ & $\begin{array}{l}83.5 \pm 7 \\
.6\end{array}$ & ------ & $\begin{array}{l}451.7 * * * * \\
\pm 19.6\end{array}$ & $440.9 \%$ & $\begin{array}{c}197.1 \\
\pm 6.4 * * *\end{array}$ & $-56.4 \%$ & $\begin{array}{l}278.4 \pm \\
22.7 * * \\
* *\end{array}$ & $-38.4 \%$ & $\begin{array}{c}116.4 \pm 8 \\
6 * * *\end{array}$ & $-74.2 \%$ \\
\hline
\end{tabular}

Significant difference at $(* \mathbf{P}<0.05, * * \mathbf{P}<0.01, * * * \mathbf{P}<0.001)$
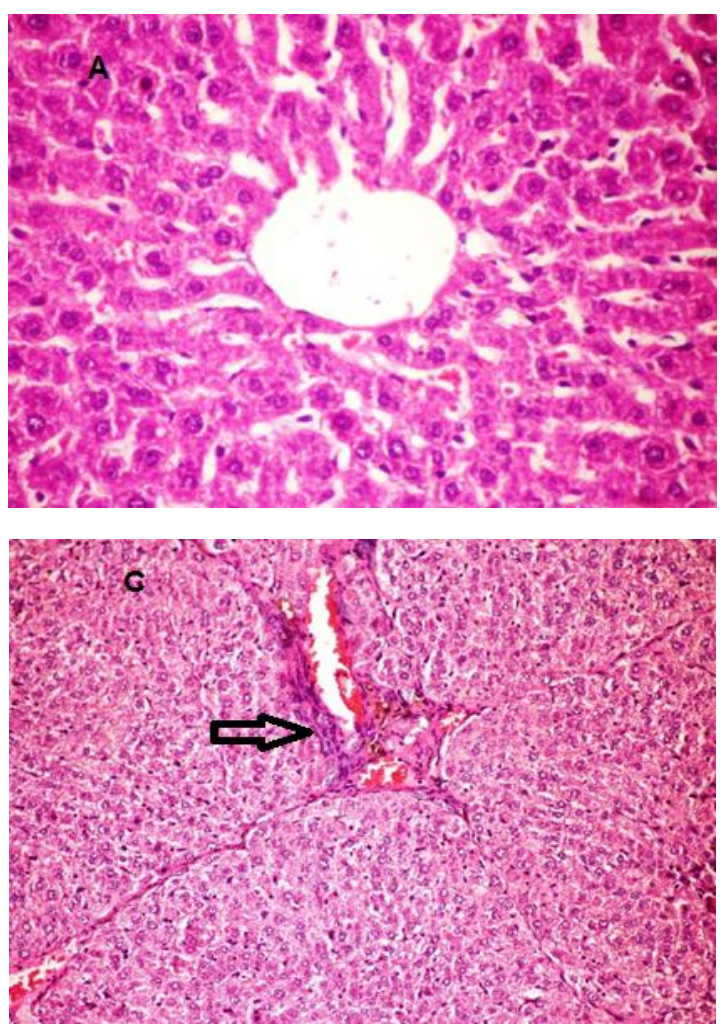
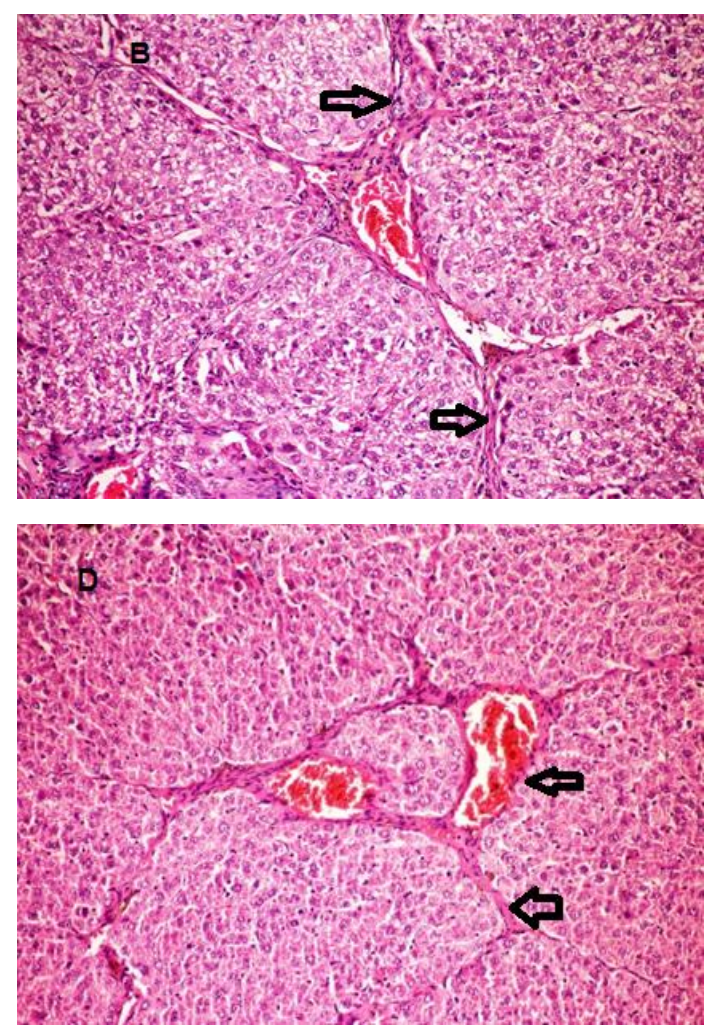

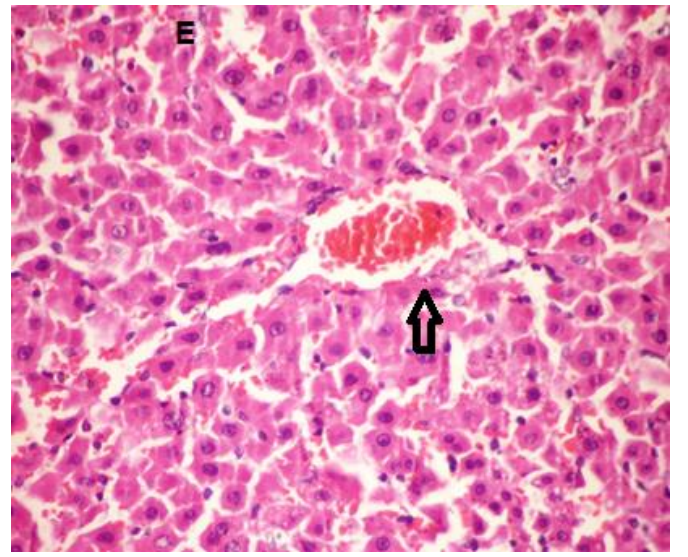

Fig. (1) The histological examinations of liver tissues in all studied groups, (H\&E X 400).

(A): A photomicrograph of Negative Control Group showing normal showed normal lobular architecture. $(\boldsymbol{B})$ : A photomicrograph of fibrotic group Liver showing portal fibrosis which encircle multiple hepatic lobules. (Arrows) (C): A photomicrograph of Banalities group Liver showing congestion of the hepatoportal blood vessel (arrow). (D): A photomicrograph of Silymarin group Liver showing hepatoportal blood vessel congestion with fibrotic nodules. (E): A photomicrograph of Combination group Liver showing congestion of the hepatoportal blood vessel (arrow) with marked regression of the degree of fibrosis 